\title{
Pemberdayaan ibu-ibu Desa Manukan Bojonegoro dalam mengembangkan Batik Jonegoroan sebagai rintisan industri kreatif
}

\section{Ngatini ${ }^{1}$, Maulin Masyito Putri ${ }^{2}$, Muhammad Faisal Ibrahim², Taufiqotul Bariyah ${ }^{1 *}$, \& Yunita Siti Mardhiyyah ${ }^{3}$}

${ }^{1}$ Program Studi Informatika, Universitas Internasional Semen Indonesia, Indonesia

2 Program Studi Teknik Logistik, Universitas Internasional Semen Indonesia, Indonesia

${ }^{3}$ Program Studi Teknologi Industri Pertanian, Universitas Internasional Semen Indonesia, Indonesia

\section{*taufiqotul.bariyah@uisi.ac.id}

\begin{abstract}
Manukan is a village in Bojonegoro Regency which is located in Gayam, Bojonegoro, East Java. The lack of family income from farmer profession requires the community to be more creative in increasing family income. Though Bojonegoro has the potential of Jonegoroan batik, which is attractive and much in demand, not many Bojonegoro people have batik knowledge and skills. Therefore, it is necessary to empower women in developing the Jonegoroan Batik creative industry. It's carried out through four stages: socialization of Batik Jonegoroan, training on how to make batik, training on developing the creative industries of batik and batik marketing. In this training, participants are trained to understand and practice the process of making batik with four technical coloring and differences between printed batik and written batik. The coloring techniques studied included colekan, semok, kelengan and laseman. Jonegoroan batik products are exhibited and sold online in marketplaces and social media, while offline in batik bazaars and exhibitions. This knowledge and skills can be used as provisions to open up business opportunities for batik craftsmen to increase family income.
\end{abstract}

Abstrak Manukan adalah salah satu desa di Kabupaten Bojonegoro yang terletak di Kecamatan Gayam, Bojonegoro, Jawa Timur. Minimnya penghasilan keluarga dari profesi petani menuntut masyarakat untuk lebih kreatif dalam meningkatkan pendapatan keluarga. Bojonegoro memiliki potensi Batik Jonegoroan yang menarik dan banyak diminati. Namun, tidak banyak masyarakat Bojonegoro yang memiliki pengetahuan dan ketrampilan membatik. Sehingga, perlu dilakukan pemberdayaan Ibu-ibu dalam mengembangkan industri kreatif Batik Jonegoroan. Pemberdayaan ini dilakukan melalui empat tahapan, yaitu sosialisasi Batik Jonegoroan, pelatihan cara membatik, pelatihan pengembangan industri kreatif batik dan pemasaran hasil batik. Dalam pelatihan ini, peserta dilatih untuk memahami dan mempraktikkan proses membatik dengan empat teknis pewarnaan dan perbedaan antara batik cap dan batik tulis. Teknis pewarnaan yang dipelajari meliputi teknik coletan, semok, kelengan dan laseman. Hasil pelatihan berupa kain Batik Jonegoroan dipamerkan dan dijual secara online di marketplace dan media sosial, sedangkan secara offline di bazar dan pameran batik. Pengetahuan dan ketrampilan ini dapat dijadikan bekal untuk membuka peluang usaha pengrajin batik oleh ibu-ibu Desa Manukan sebagai salah satu upaya meningkatkan pendapatan keluarga.
17

\section{ठ OPEN ACCESS}

Citation: Ngatini, Putri, M.M, Ibrahim, M.F., Bariyah, T., \& Mardhiyyah, Y.S. (2020).

Pemberdayaan ibu-ibu Desa Manukan Bojonegoro dalam mengembangkan Batik Jonegoroan sebagai rintisan industri kreatif. Riau Journal of Empowerment, 3(1), 17-25. https://doi.org/10.31258/raje.3.1.17-25

Paper type: Community service

Received: 2019-08-22 Revised: 2019-12-03 Accepted: 2019-12-09

Language: Bahasa Indonesia (id)

Funding: Kementerian Riset, Teknologi, dan Pendidikan Tinggi Republik Indonesia.

ISSN 2623-1549 (online), 2654-4520 (print)

(C) 2020 Ngatini et al. Author(s) retain the copyright of article published in this journal, with first publication rights granted to Riau Journal of Empowerment. The article is licenced under Creative Commons Attribution 4.0 International License. This license permits unrestricted use, distribution, and reproduction in any medium, provided the original author and source are credited. 
Keywords: printed batik; Batik Jonegoroan; traditional batik; Bojonegoro; creative industry; farmers

\section{PENDAHULUAN}

Bojonegoro merupakan sebuah kabupaten yang terletak di Provinsi Jawa Timur, Indonesia. Kabupaten Bojonegoro berbatasan dengan Kabupaten Tuban di utara, Kabupaten Lamongan di timur, Kabupaten Nganjuk, Madiun, dan Ngawi di selatan, serta Kabupaten Blora, Jawa Tengah, di barat (Pemerintah Kabupaten Bojonegoro, 2018). Sepanjang selatan hingga timur di wilayah utara Bojonegoro membentang Bengawan Solo yang merupakan sumber mata air untuk kehidupan sehari-hari maupun sumber irigasi bagi pertanian di daerah tersebut. Bagian utara dari daerah aliran sungai Bengawan Solo merupakan daerah pertanian yang subur dan kebanyakan masyarakat yang tinggal di daerah tersebut berprofesi sebagai seorang petani. Profesi petani di daerah tersebut tidak hanya didominasi oleh Bapak-bapak saja namun Ibuibu juga banyak berperan dalam proses pertanian tersebut. Salah satu desa yang merupakan bagian utara di sepanjang sungai Bengawan Solo adalah Desa Manukan di kecamatan Gayam. Hampir seluruh masyarakat yang tinggal di desa tersebut berprofesi sebagai seorang petani mulai dari Bapak-bapak hingga Ibu-ibu, baik yang mempunyai tanah sendiri atau sebagai buruh tani.

Petani yang hanya mengandalkan penghasilan dari bercocok tanam saja, selama ini merasakan panen tidaklah mencukupi untuk kebutuhan sehari-hari. Selain masalah tersebut, mahalnya perlengkapan pertanian seperti pupuk dan pestisida menjadikan petani harus memiliki cukup modal untuk menanam padi. Hal ini membuat petani harus melakukan pinjaman uang ke bank dengan jaminan Buku Pemilik Kendaraan Bermotor (BPKB) atau surat tanah yang nantinya akan dibayar saat panen tiba. Kebanyakan petani melakukan peminjaman uang di bank di awal musim tanam padi. Modal hutang ini tidak sebanding dengan keuntungan yang diperoleh dari hasil panen nantinya, apalagi jika petani gagal panen.

Waktu untuk petani bekerja di sawah mulai dari pembibitan sampai dengan pemupukan padi membutuhkan kira-kira 57 hari atau dua bulan, waktu hingga masa panen adalah masa tunggu petani. Saat masa tunggu panen kurang lebih 45 hari (1,5 bulan), petani tidak banyak bekerja di sawah sehingga rata-rata ibu-ibu petani hanya bekerja di rumah sebagai ibu rumah tangga. Masa tunggu panen inilah adalah waktu luang dari ibu-ibu petani yang harusnya dimanfaatkan untuk suatu kegiatan yang produktif. Namun kegiatan yang dilakukan ibu-ibu tidak lebih hanya di rumah untuk memasak dan membersihkan rumah saja.

Penghasilan rata-rata dari ibu-ibu di Desa Manukan hanya bergantung pada panen padi tiap tiga bulan sekali, padahal dalam sekali masa panen belum tentu petani mendapatkan untung yang mencukupi kebutuhan tiga bulan kedepannya. Sehingga dibutuhkan sebuah pemberdayaan khususnya bagi Ibu-ibu dalam mengembangkan sebuah industri kreatif yang mampu menunjang penghasilan kedepannya. Salah satu yang menarik dan saat ini dikembangkan adalah Batik Jonegoroan yang merupakan Batik khas Kabupaten Bojonegoro.

Batik merupakan salah satu warisan budaya Indonesia yang mempunyai corak beragam bergantung pada daerah asal batik diproduksi. Batik berasal dari kata 'amba' yang berarti menulis dan 'nitik' yang berarti titik (Iskandar \& Kustiyah, 2017). Motif batik tradisional mempunyai makna berbeda dan kaya akan kearifan lokal dengan pesan dan harapan kehidupan (Parmono, 2013). Kebudayaan batik di Indonesia yang telah diakui pada tingkat Internasional oleh UNESCO pada tanggal 2 Oktober 2009 lalu menjadi inspirasi bagi masyarakat Bojonegoro untuk mengkreasikan batik khas daerah Bojonegoro sebagai khasanah 
kebudayaan nasional Indonesia. Batik khas Bojonegoro ini berawal dari ide bupati Bojonegoro yang ditindak lanjuti dengan mengadakan perlombaan mendesain motif batik yang sesuai dengan potensi asli Bojonegoro. Batik Jonegoroan sendiri adalah batik khas Bojonegoro yang memiliki karakteristik kultural khas Bojonegoro (At Tanthowy, 2015). Batik tersebut merupakan bentuk kreasi masyarakat Bojonegoro terhadap kebudayaan batik nasional. Batik Jonegoroan merupakan batik khas Bojonegoro yang di-launching dengan 9 motif khas Bojonegoro oleh Pemerintah Kabupaten Bojonegoro pada tahun 2009 pada acara pemilihan Duta Wisata Bojonegoro (Utami, 2011). Karakter dan motif Batik Jonegoroan banyak terinspirasi dari kebudayaan dan kekayaan Bojonegoro. Baik kekayaan alam, kesenian, maupun pariwisata di wilayah Bojonegoro (Octaviani, 2015).

Pemerintah Kabupaten Bojonegoro selama ini melakukan beberapa upaya dalam rangka mensosialisasikan Batik Jonegoroan. Sosialisasi yang sudah dilaksanakan meliputi kegiatan workshop dan seminar yang dilakukan pemerintah Bojonegoro (Wardani, 2011). Selain sosialisasi tersebut, PKK kabupaten Bojonegoro telah melakukan pelatihan kepada ibu-ibu di Tirtawana Dander tahun 2009 silam. Namun pelatihan dari Batik Jonegoroan belum sepenuhnya merata di setiap desa di Bojonegoro, seperti di Desa Manukan yang merupakan desa di bagian ujung barat dari kota Bojonegoro.

Masyarakat desa di Bojonegoro sendiri tidak seluruhnya mengenal tentang Batik Jonegoroan yang merupakan ikon dari Bojonegoro. Kebanyakan masyarakat desa di Bojonegoro masih berprofesi sebagai petani, sehingga pengetahuan tentang membatik masih sangat minim. Padahal membatik menjadi salah satu keterampilan yang berpotensi dikembangkan dalam waktu tunggu panen yang membutuhkan waktu sekitar dua sampai tiga bulan. Industri batik sendiri meskipun sempat mengalami pasang surut masih memiliki peluang yang cukup besar, terutama karena animo masyarakat terhadap produk batik masih tinggi (Nurainun et al., 2008). Oleh karena itu, diperlukan suatu program pelatihan membatik yang menarik di Balai Desa Manukan untuk ibu-ibu petani guna menambah keahlian di bidang kerajinan membatik sekaligus sebagai langkah awal untuk merintis industri Batik Jonegoroan.

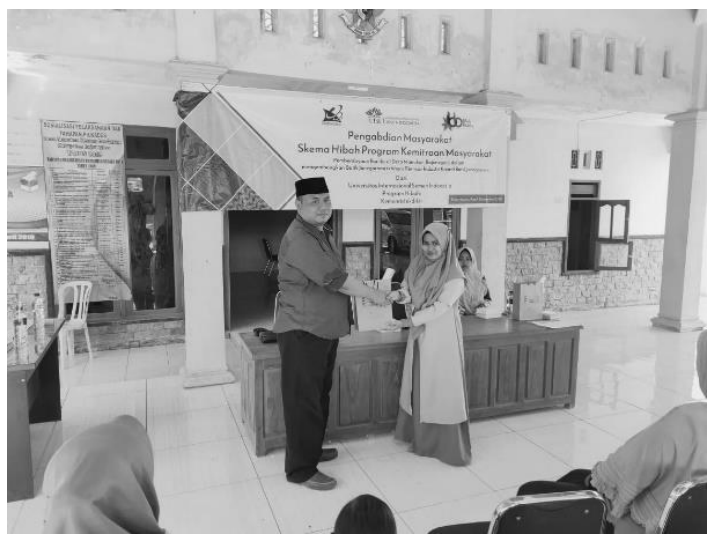

(a)

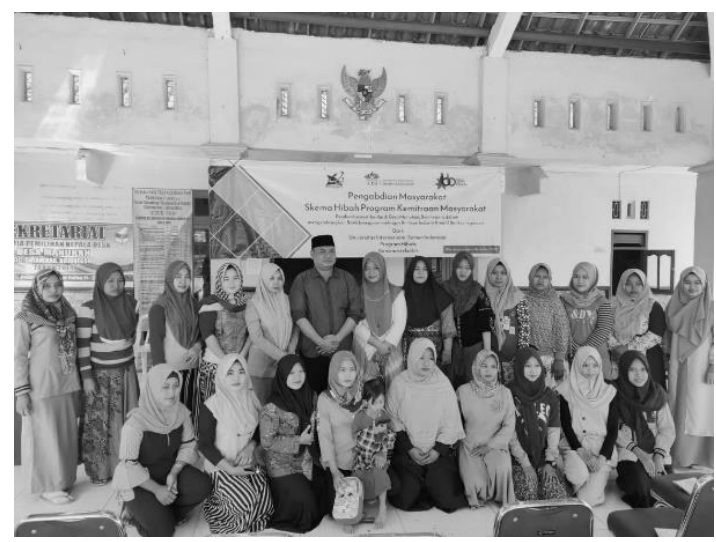

(b)

Gambar 1. (a) Pembukaan acara oleh Kepala Desa, dan (b) ibu-ibu peserta pelatihan dan sosialisasi Batik Jonegoroan

\section{METODE PENERAPAN}

Sasaran kegiatan pengabdian masyarakat ini adalah ibu-ibu Desa Manukan, Kecamatan Gayam, Kabupaten Bojonegoro. Kegiatan pemberdayaan dilakukan bersama 29 orang ibu-ibu 
Desa Manukan, yang dibagi menjadi lima kelompok kecil berdasarkan teknik membatik. Proses membatik Jonegoroan yang dilakukan pada pelatihan ini terdiri dari empat teknik, yaitu teknik coletan, teknik semok, teknik kelengan dan teknik laseman. Adapun perbedaan dari masing-masing teknik adalah sebagai berikut:

1. Teknik Coletan adalah proses membatik dengan teknik mewarnai yang dicolet (diwarnai secara manual dengan kuas). Teknik ini dikenal sebagai teknik yang paling memberikan hasil memuaskan dan juga harga produk yang lebih tinggi.

2. Teknik Semok adalah proses membatik dengan teknik mewarnai yang terdiri dari warna dasar dan warna tambahan. Pada teknik ini pola batik terdiri dari warna dasar (warna lebih terang) dan warna seperti asap (warna lebih gelap).

3. Teknik Kelengan adalah proses membatik dengan teknik satu warna sebagai warna dasar.

4. Teknik Laseman yaitu proses membatik dengan dua warna yaitu warna dasar dan warna pada pola batik.

Secara keseluruhan, rangkaian kegiatan pemberdayaan ibu-ibu Desa Manukan terdiri atas beberapa kegiatan berikut:

1. Sosialisasi Batik Jonegoroan

Sosialisasi mengenai Batik Jonegoroan yang ditunjukkan oleh Gambar 1. Sosialisasi disini sangat penting untuk mengenalkan masyarakat tentang Batik khas Bojonegoro yaitu Batik Jonegoroan. Di samping itu juga untuk melestarikan kebudayaan yang telah dimiliki saat ini. Dalam sosialisasi tersebut akan dilengkapi dengan modul yang nantinya dapat dibaca dan dipelajari secara mandiri oleh Ibu-ibu Desa Manukan.

2. Pelatihan Cara Membatik

Tahap selanjutnya setelah masyarakat mengetahui dan mengenal Batik Jonegoroan adalah diadakannya pelatihan cara membatik bagi Ibu-ibu Desa Manukan. Dalam pelatihan tersebut akan dijelaskan mengenai cara menggambar pola Batik, membatik dengan menggunakan canting (batik tulis), melorot hingga mewarnai. Kegiatan ini didampingi oleh dua orang narasumber pengrajin batik Bojonergoro.

3. Pelatihan Industri Kreatif Batik Jonegoroan

Tujuan jangka panjang dari pelatihan tersebut adalah terciptanya iklim Industri Kreatif Batik Jonegoroan di lingkungan Desa Manukan dengan penggeraknya adalah Ibu-ibu Desa Manukan. Dalam industri kreatif tersebut Ibu-ibu akan dibekali mengenai proses pemasaran baik secara offline maupun digital.

4. Mengikuti pameran maupun pemasaran Batik

Batik yang dihasilkan oleh Ibu-ibu nanti harapannya dapat diikutkan dalam pameran maupun pemasaran Batik. Sehingga masyarakat luas dapat menikmati hasil kerajinan yang telah dibuat oleh Ibu-ibu.

Menurut teknik pembuatannya, batik dibedakan menjadi tiga jenis, yaitu batik tulis, batik cap, dan batik lukis (Prasetyo, 2016). Dalam pelatihan ini digunakan teknik batik cap atau batik cetak. Batik cap sendiri adalah batik yang dihasilkan dari proses mengecap atau mencetak kain dengan menggunakan cap atau stempel dengan pola batik tertentu. Pola atau motif batik ini tentunya akan menghasilkan batik dengan pola pengulangan yang sama, teraur, dan simetris (Supriyono, 2017).

Adapun alat dan bahan yang diperlukan dalam pelatihan ini antara lain adalah panci, wajan grengseng dan meja tatakan, meja membatik (yang sudah tersusun dengan sponge, plastik 
kaca, dan air), bentangan mewarnai, kain, malam/lilin, pewarna, canting, dan alat cap. Alat cap yang digunakan merupakan alat cap manual yang terbuat dari besi. Alat dan bahan ini sebagaimana yang ditunjukkan dalam Gambar 2. Pola yang digunakan adalah pola Sekar Jati dan pola Belimbing Lining Lima.

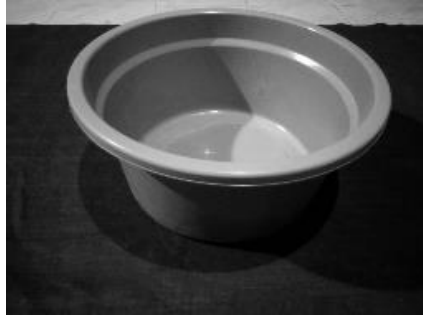

(a)

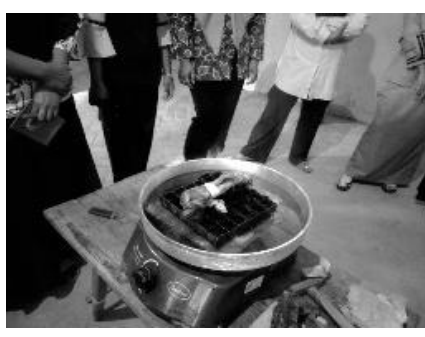

(d)

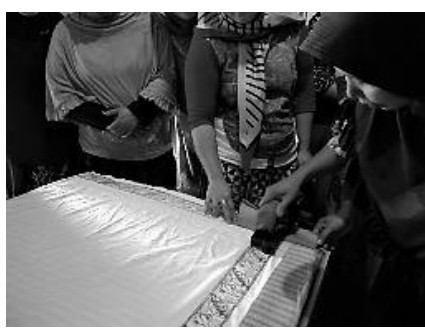

(g)

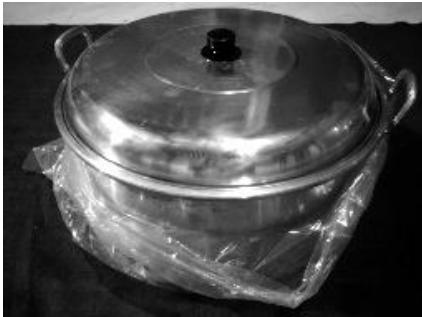

(b)

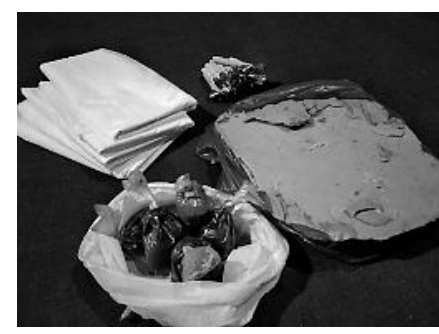

(e)

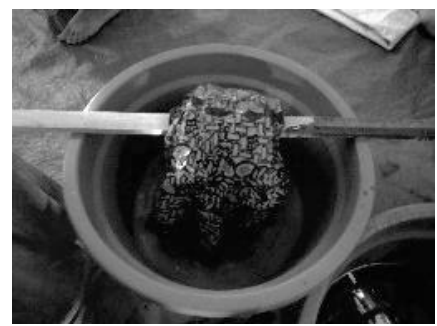

(h)

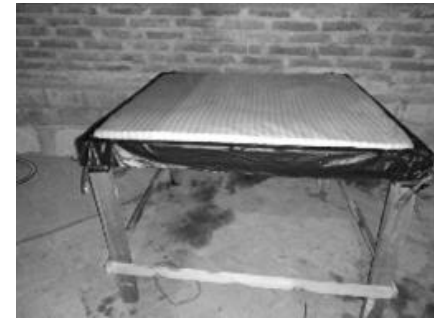

(c)

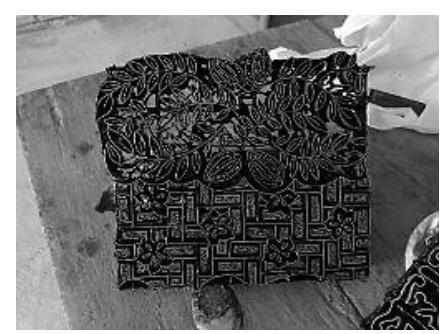

(f)

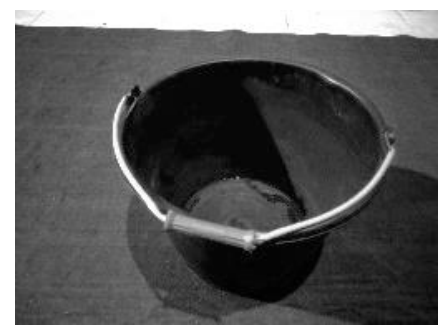

(i)

Gambar 2. Alat dan bahan yang digunakan (a) bak, (b) panci, (c) meja membatik, (d) kompor, (e) malam dan pewarna, (f) alat cap, (g) kain, (h) bentangan mewarnai, dan (i) timba

\section{HASIL DAN KETERCAPAIAN SASARAN}

Sebelum melaksanakan kegiatan pengabdian masyarakat ini, terlebih dahulu dilakukan pengumpulan fakta dan informasi terkait Batik Jonegoroan dan informasi tentang kegiatan yang dilakukan ibu-ibu Desa Manukan selama masa tunggu panen. Hasil dari survei ini didapatkan bahwa kebanyakan ibu-ibu Desa Gayam mempunyai waktu luang selama masa tunggu panen tetapi pengetahuan mereka tentang Batik Jonegoroan masih kurang sebagaimana yang ditunjukkan dalam Gambar 3 dan Gambar 4.

Jumlah peserta pelatihan terdiri dari 29 ibu-ibu dari Desa Manukan. Berdasarkan Gambar 3 menunjukan bahwa sebanyak 58\% peserta telah mengetahui apa itu Batik Jonegoroan, sedangkan sebanyak $42 \%$ peserta masih belum mengetahui tentang Batik Jonegoroan. Melihat persentase peserta yang belum mengetahui tentang Batik Jonegoroan sebanyak $42 \%$ menunjukkan bahwa perlunya dilakukan sosialisasi mengenai Batik Jonegoroan.

Jenis pelatihan membatik yang dilaksanakan adalah membatik cap dengan pola batik khas Jonegoroan. Sebelum dilaksanakannya pelatihan dilakukan terlebih dahulu survey mengenai kemampuan membatik dari peserta. Hal tersebut digambarkan pada Gambar 4 yang menjelaskan mengenai kemampuan peserta dalam membatik Cap sebelum dilaksanakannya 
pelatihan. Kuesioner tersebut menunjukkan bahwa sebanyak 54\% Ibu-ibu tidak mengetahui dan tidak mampu menjelaskan langkah-langkah membatik cap, kemudian sebanyak $42 \%$ Ibuibu mampu menjelaskan namun kurang tepat, dan hanya $4 \%$ saja yang mampu menjelaskan dengan benar. Hasil survey tersebut menunjukkan bahwa kemampuan dalam membatik dari Ibu-ibu Desa Manukan masih rendah, sehingga diperlukannya pelatihan membatik cap. Secara keseluruhan ibu-ibu yang menjadi peserta pelatihan sangat antusias dan ingin mengikuti keseluruhan pelatihan yang akan dilaksanakan.

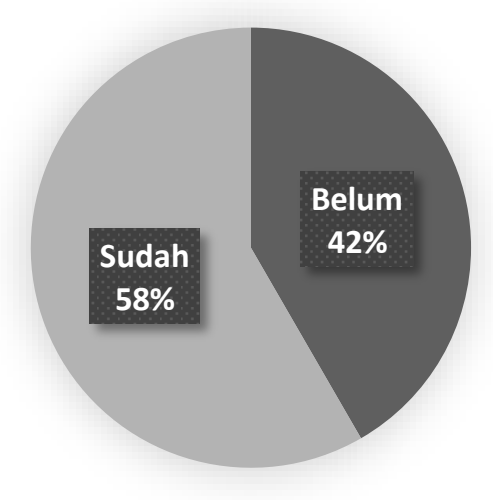

Gambar 3. Persentase peserta yang mengetahui Batik Jonegoroan

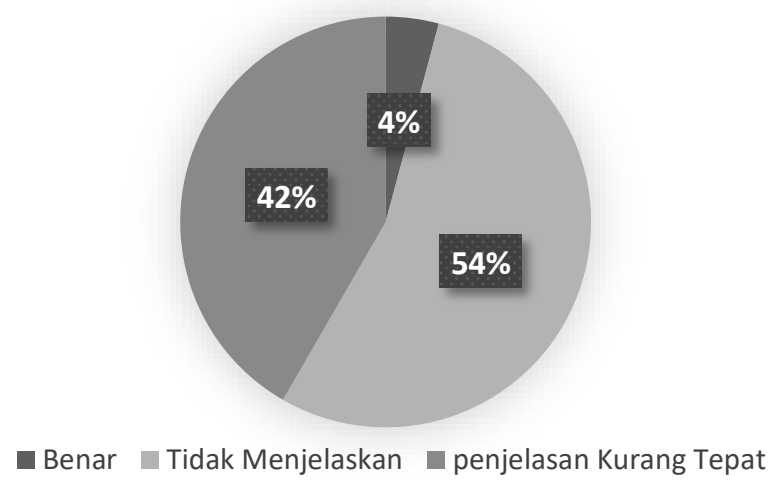

Gambar 4. Jumlah peserta yang mampu menjelaskan langkah-langkah batik cap

Kegiatan pelatihan batik bagi ibu-ibu Desa Manukan, Kecamatan Gayam, Kabupaten Bojonegoro ini dilakukan secara intensif selama lima hari dengan mengundang narasumber dari Batik Training Center (BTC). Ibu-ibu peserta mempelajari dan mempraktikkan proses pembuatan pola/cap batik, dilanjutkan dengan proses pewarnaan batik dan proses pelorotan malam atau pencucian yang ditunjukkan pada Gambar 5 .

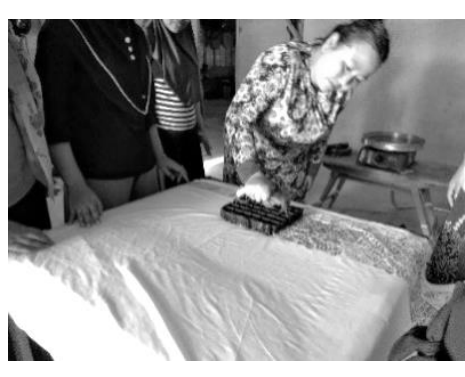

(a)

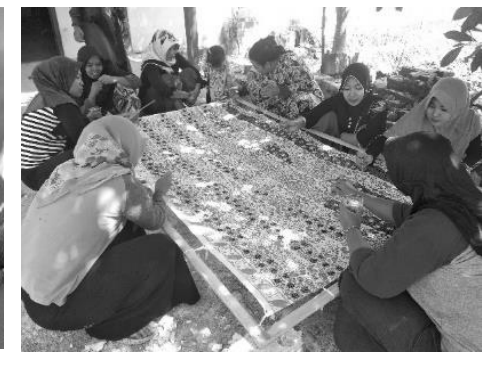

(b)

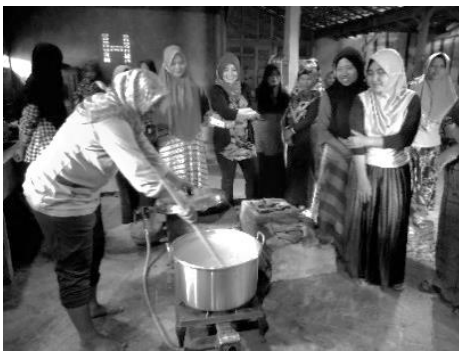

(c)

Gambar 5. Proses pembatikan (a) membatik cap, (b) pewarnaan batik, dan (c) pelorotan malam/lilin 
Peserta pelatihan dibagi menjadi 5 kelompok yang terdiri dari 5-6 peserta per kelompok Pada pelatihan ini disediakan kain berukuran 1x1 m untuk setiap kelompok sebagai latihan membatik. Pembagian kelompok dan teknik pewarnaan dilakukan sebagai berikut:

Kelompok 1: Teknik Coletan dengan pola Belimbing Lining Lima

Kelompok 2: Teknik Semok dengan pola Belimbing Lining Lima

Kelompok 3: Teknik Kelengan dengan pola Sekar Jati

Kelompok 4: Teknik Coletan dengan pola Sekar Jati

Kelompok 5: Teknik Laseman dengan pola Sekar Jati

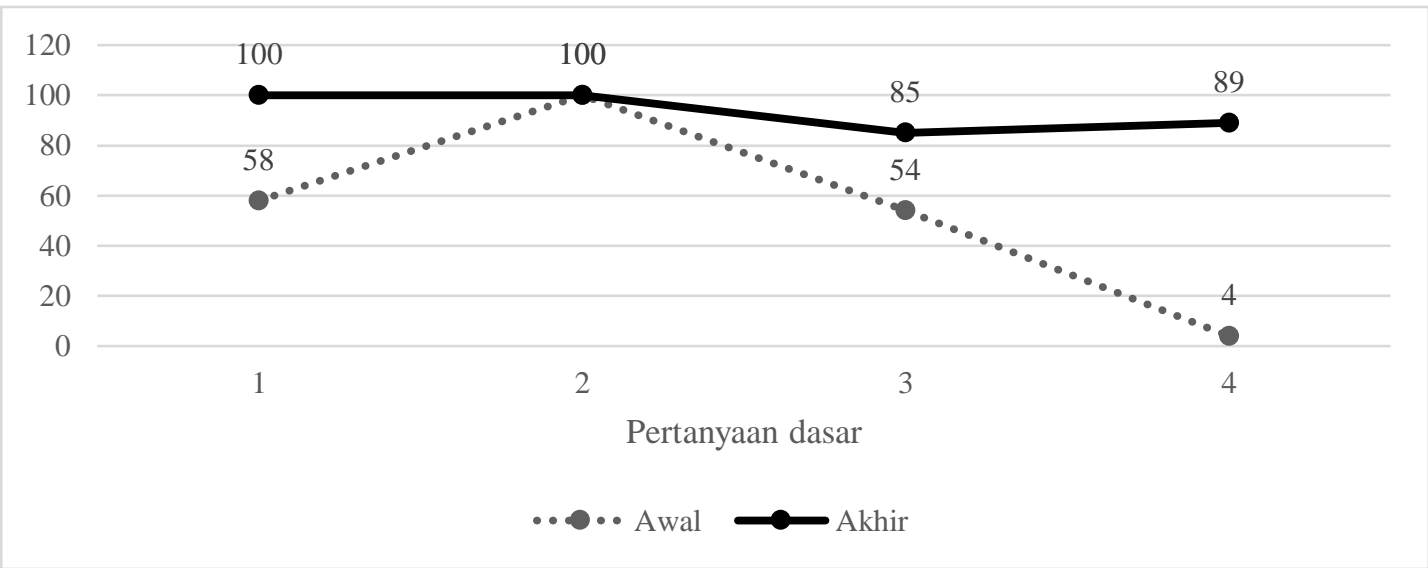

Gambar 6. Hasil tes kemampuan dasar (\%) peserta pelatihan membatik yang diuji pada awal dan akhir kegiatan pengabdian
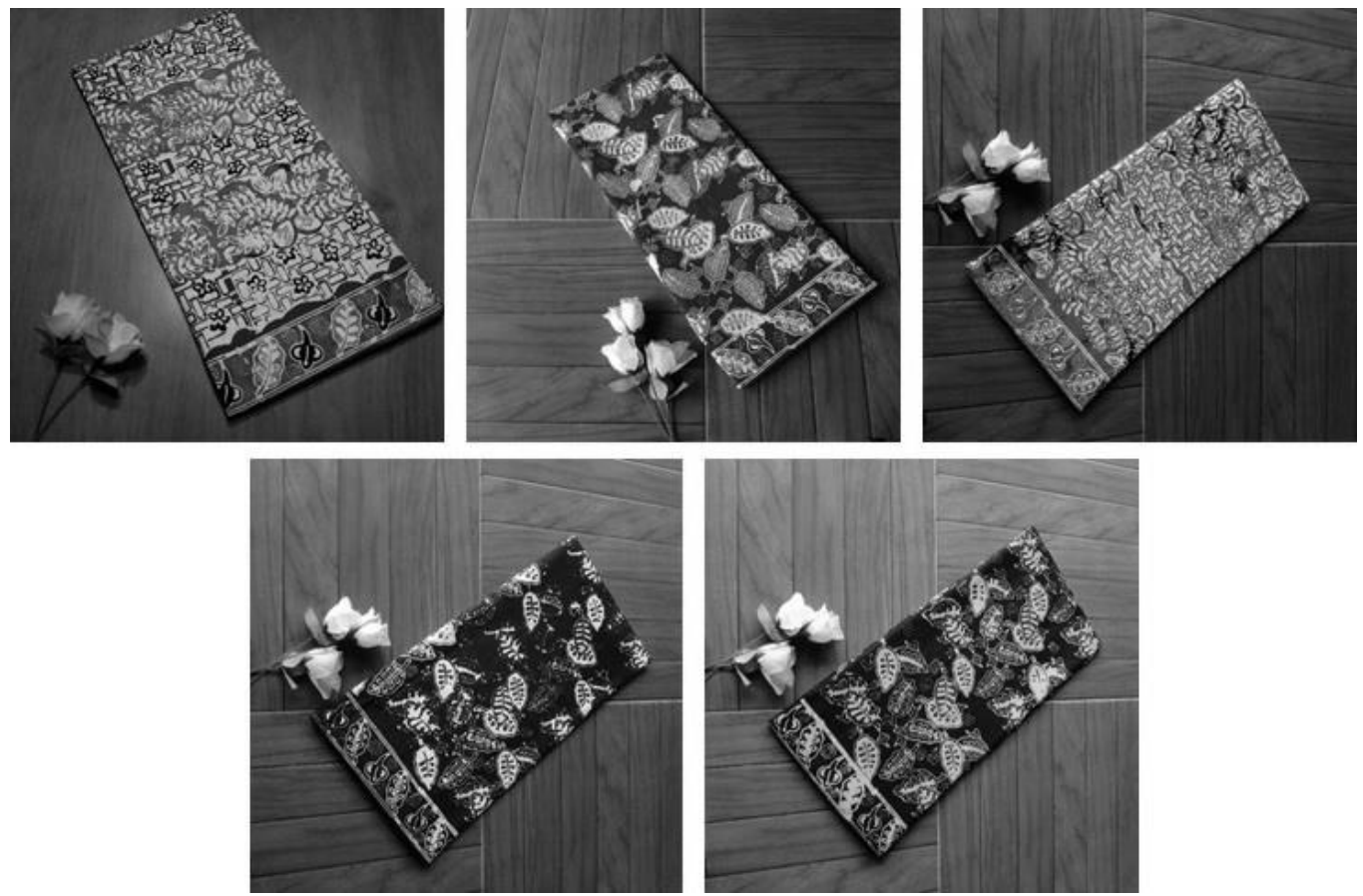

Gambar 7. Kain hasil pelatihan Batik Jonegoroan 
Hasil post test (tes akhir) pelatihan menunjukkan bahwa $89 \%$ peserta memahami dan dapat mempraktikkan proses membatik dengan empat teknis pewarnaan. Peserta juga memiliki pemahaman perbedaan teknik pembuatan batik cap dan batik tulis. Pengetahuan dan ketrampilan ini dapat dijadikan bekal untuk membuka peluang usaha pengrajin batik oleh ibuibu Desa Manukan sebagai salah satu upaya meningkatkan pendapatan keluarga. Hasil tes kemampuan dasar baik pre test maupun post test ini dapat dilihat pada Gambar 6.

Hasil pelatihan batik berupa lima kain batik dengan menggunakan empat teknik pewarnaan yang berbeda. Kain batik yang telah dibuat seperti pada Gambar 7 selanjutnya dipamerkan dan dijual di beberapa bazar yang diadakan di dalam dan luar Bojonego sebagaimana terlihat pada Gambar 8. Selain itu, penjualan kain dipasarkan melalui salah satu marketplace dan media sosial. Selanjutnya akan diadakan kegiatan pengembangan kegiatan membatik oleh ibu-ibu PKK.

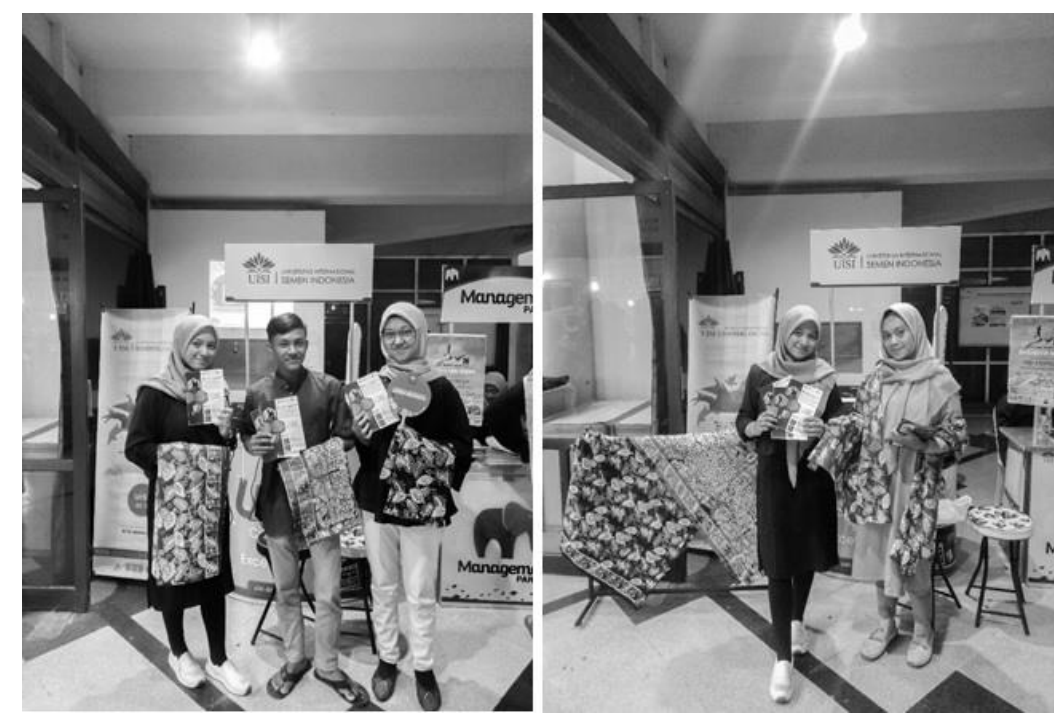

Gambar 8. Kegiatan penjualan dan pameran batik di bazar

\section{KESIMPULAN}

Pemberdayaan ibu-ibu Desa Manukan, Kecamatan Gayam, Kabupaten Bojonegoro telah berhasil meningkatkan pengetahuan dan ketrampilan membatik. Sejumlah $42 \%$ peserta yang sebelumnya belum mengetahui teknik membatik Batik Jonegoroan, menjadi $89 \%$ peserta memahami dan dapat mempraktikkan proses membatik dengan empat teknis pewarnaan. Teknis pewarnaan yang dipelajari meliputi teknik coletan, semok, kalengan dan laseman. Peserta juga memiliki pemahaman perbedaan teknik pembuatan batik cap dan batik tulis. Hasil pelatihan berupa kain Batik Jonegoroan dipamerkan dan dijual secara online di marketplace dan media sosial, sedangkan secara offline di bazar dan pameran batik. Pengetahuan dan keterampilan ini dapat dijadikan bekal untuk membuka peluang usaha pengrajin batik oleh ibu-ibu Desa Manukan sebagai salah satu upaya meningkatkan pendapatan keluarga. 


\section{UCAPAN TERIMA KASIH}

Penulis menyampaikan terima kasih kepada Kementerian Riset, Teknologi, dan Pendidikan Tinggi, Lembaga Penelitian dan Pengabdian Masyarakat (LPPM) Universitas Internasional

\section{Daftar Pustaka}

1. At Tanthowy, H. (2015). Ragam Motif Batik Bojonegoro Sebagai Upaya Membangun Identitas Daerah Di Bojonegoro Tahun 2009-2014. Avatara, e-Journal Pendidikan Sejarah, 3(3), 326334. https://jurnalmahasiswa.unesa.ac.id/index.php/avatara/article/view/12501/11540

2. Iskandar, \& Kustiyah, E. (2017). Batik sebagai identitas kultural bangsa Indonesia di era globalisasi. Gema, 30(52), 2456-2472.

3. Nurainun, Heriyana, \& Rasyimah. (2008). Analisis Industri Batik di Indonesia. Fokus Ekonomi, 7(3), 124-135. https://www.unisbank.ac.id/ojs/index.php/fe2/article/view/1647

4. Octaviani, R.N. (2015). Dampak Pengakuan Batik dari Unesco Terhadap Motif Batik Jonegoroan sebagai Identitas Batik pada Masyarakat Bojonegoro di Desa Jono Kecamatan Temayang Kabupaten Bojonegoro (Undergraduate Thesis). Universitas Negeri Semarang, Semarang, Indonesia.

5. Parmono, K. (2013). Nilai Kearifan Lokal dalam Batik Tradisional Kawung. Jurnal Filsafat, 23(2), 134-146. https://doi.org/10.22146/jf.13217

6. Pemerintah Kabupaten Bojonegoro. (2018, October 26). Kondisi Geografis Kabupaten Bojonegoro. Retrieved from http://www.bojonegorokab.go.id/geografi

7. Prasetyo, S.A. (2016). Karakteristik Motif Batik Kendal Interpretasi dari Wilayah dan Letak Geografis. Jurnal Imajinasi, 10(1), 51-60. https://journal.unnes.ac.id/nju/index.php/imajinasi/article/view/8816

8. Supriyono, Y.P. (2017). Ensiklopedia The Heritage of Batik, Identitas Pemersatu Kebanggaan Bangsa. Yogyakarta, Indonesia: Andi Publisher.

9. Utami, P.S. (2011). Makna Simbolik Kreasi Batik Khas Daerah Bojonegoro sebagai Kekayaan Budaya Nasional (Undergraduate Thesis). Universitas Negeri Malang, Malang, Indonesia.

10. Wardani, L.S. (2011). Peranan Dinas Perindustrian dan Perdagangan dalam Pemberdayaan Pengrajin Batik Jonegoroan di Desa Jono Kecamatan Temayang Kabupaten Bojonegoro. Jurnal Pendidikan Kewarganegaraan Universitas Negeri Malang, 1(1). 